\title{
Rose Germplasm Analysis with RAPD Markers
}

\author{
C.H. Jan ${ }^{1}$ and D.H. Byrne ${ }^{2}$ \\ Department of Horticultural Sciences, Texas A\&M University, College Station, \\ TX 77843-2133
}

\author{
J. Manhart ${ }^{2}$ and H. Wilson ${ }^{2}$ \\ Department of Biology, Texas A\&M University, College Station, TX77843-3258
}

Additional index words. Rosa, phenetics, classification

\begin{abstract}
The genus Rosa consists of more than 100 species classified into four subgenera, Eurosa, Platyrhodon, Hesperhodos, and Hulthemia, and distributed widely throughout the northern hemisphere. The subgenus Eurosa includes 11 sections. The other subgenera are monotypic. One hundred and nineteen accessions and 213 markers of 36 rose species that include eight sections of the subgenus Eurosa and one species each from the subgenera Hesperhodos and Platyrhodon were used to calculate a similarity matrix, which was clustered with the unweighted pair group method using arithmetic means (UPGMA). The RAPD markers distinguished between all the rose accessions, and species grouped into their respective sections. Therefore, classification of Rosa using RAPD data generally supports traditional classification. The Asian rose sections (Laevigatae, Banksianae, Bracteatae, Pimpinellifoliae, Chinenses, and Synstylae) were consistently separated from the primarily North American sections (Cassiorhodon and Carolinae). The Cassiorhodon and Carolinae sections were grouped together with the subgenera Hesperhodos and Platyrhodon. Both subgenera separated out at the same level as sections within the subgenus Eurosa, suggesting that they are more appropriately classified as sections within the subgenus Eurosa. Sections Cassiorhodon and Carolinae overlapped, and are probably best grouped as one section as previously suggested.
\end{abstract}

Roses are one of the most important flower and nursery crops throughout the world. About 60 million rose plants for garden use are propagated in the United States (Streeper, 1990) and $\$ 300$ million is generated by the cut flower market annually (U.S. International Trade Commission, 1995). The demand for greater disease resistance has led to the use of more wild rose species in breeding and the development of unique interspecific derived germplasm, such as amphidiploids (Byrne et al., 1996). Unfortunately, this work is limited by the dearth of information available about the genetic relationships among rose species.

The genus Rosa consists of more than 100 species, the exact number varying with the classification system (Allen, 1973; Rehder, 1940). Their wide geographic distribution, polyploidy, and frequent interspecific hybridization, together with human involvement, makes this genus diverse and difficult to classify. Traditional identification and classification of plants are based on morphological characteristics (Allen, 1969, 1973; Bean, 1970;

\footnotetext{
Received for publication 16 Nov. 1997. Accepted for publication 11 Aug. 1998. Research conducted in partial fulfillment of a Master of Science degree by Chih-Hui Jan. The cost of publishing this paper was defrayed in part by the payment of page charges. Under postal regulations, this paper therefore must be hereby marked advertisement solely to indicate this fact.

${ }^{1}$ Graduate student.

${ }^{2}$ Professor.
}

Erlanson, 1934; Flory, 1950; Lewis, 1957a, 1957b, 1958, 1970; Rehder, 1940). Because each species of the genus Rosa has a wide and overlapping range of morphological variations that are influenced by environmental conditions, classification based on morphology alone is not adequate (Lewis, 1957b). Chemotaxonomic studies of roses (Mikanagi et al., 1993, 1994; Okuda et al., 1992; Raymond et al., 1995) based on the wide range of variant polyphenolic compounds have been reported. Isozyme markers have also been used for rose identification (Kim and Byrne, 1996; Kuhns and Fretz, 1978a, 1978b; Lee and Kim, 1982; Walker and Werner, 1997; Yoneda et al., 1993) and classification (Kim, 1994; Kim and Byrne, 1994). However, the small number of consistently resolvable loci (Kim, 1994; Kim and Byrne, 1994) limits the utility of isozyme markers. Direct DNA-based diagnostic assays are considered powerful and reliable tools for genetic analysis because the number of scorable loci is greater, and expression is similar in all tissues (Hubbard et al., 1992; Torres et al., 1993). DNA markers, such as restriction fragment length polymorphisms (RFLPs) (Hubbard et al., 1992), random amplified polymorphic DNA (RAPD) (Gallego and Martinez, 1996; Torres et al., 1993; Walker and Werner, 1997), and mini- and microsatellite probes (Vainstein and Ben-Meir, 1994) have been used for rose identification, but only recently has preliminary taxonomic research been done with RAPD analysis (Debener et al., 1996; Millan et al., 1996).

Random amplified polymorphic DNA
(RAPD) markers (Williams et al., 1990) have been widely used for determining variety and parentage identification, construction of highdensity genetic maps, targeted mapping for specific traits with bulk segregant analysis or near-isogenic lines, and studying genetic diversity and phylogenetic relationships (He et al., 1992; Hu and Quiros, 1991; Kresovich et al., 1992; Tingey et al., 1993; Welsh et al., 1991). This method uses genomic DNA as a template, is rapid, does not employ radioisotopes, and only requires nanograms of DNA per reaction (Williams et al., 1990).

The objective of this study was to use RAPD markers to classify 36 rose species using a phenetic analysis for interpretation.

\section{Materials and Methods}

Plant materials. One hundred and nineteen rose genotypes representing 36 species were surveyed. One to 11 species (mainly diploid) were selected to represent eight of 11 sections within the subgenus Eurosa and one species each from the subgenera Platyrhodon and Hesperhodos (Table 1). Young leaves were collected from the greenhouse, screenhouse, and field, put into labeled envelopes, and stored in an ice chest for transport to the laboratory. In the laboratory the leaves were stored at -20 ${ }^{\circ} \mathrm{C}$ in a freezer until their DNA was extracted.

DNA isolation. A minipreparation protocol utilizing a cationic hexadecyl trimethyl ammonium bromide (CTAB) method modified from Doyle and Doyle (1987) and Paterson et al. (1993) was used. Modifications were designed to counter the high level of secondary compounds found in rose leaves. These compounds degrade DNA, and inhibit subsequent enzyme digests and PCR reactions. The modifications included the use of 2-mercaptoethanol as an antioxidant, and further purification through phenol extraction and gel filtration.

Young leaf tissue (50-70 mg) was ground with liquid nitrogen in a $1.5-\mathrm{mL}$ microfuge tube. The powder was then mixed with $1 \mathrm{~mL}$ $4 \mathrm{X} \mathrm{CTAB}$ solution and $2.5 \mu \mathrm{L}$ 2-mercaptoethanol. The homogenate was incubated in a 65 ${ }^{\circ} \mathrm{C}$ water bath for $1-2 \mathrm{~h}$ with periodic gentle vortexing, and the DNA was extracted twice with 24 chloroform : 1 isoamyl alcohol (CIA) and twice with 25 phenol : 24 chloroform : 1 isoamyl alcohol. The final pellet was dissolved in $150 \mu \mathrm{L}$ TE buffer (10 mM Tris- $\mathrm{HCl}$, $\mathrm{pH} 7.5,0.1$ mm EDTA), and further purified by gel filtration with 5\% Sephadex G-50 gel column constructed from a 1.5 -mL microcentrifuge tube. DNA concentration was determined by $0.8 \%$ agarose gel electrophoresis in TE buffer (Sambrook et al., 1989) and comparison of band intensities with lambda DNA standards. All DNA samples were diluted to $0.25 \mathrm{ng} \cdot \mu \mathrm{L}^{-1}$ before use.

$R A P D$ assay. The ten 10-base-long arbitrary primers (Operon Technologies, Alameda, Calif.) that gave the most reproducible and polymorphic patterns were selected from 80 primers (KitE, F, G, H). Those used were E14, E19, F06, F14, G11, G19, H06, H12, H15, and H19. Amplification reactions were performed 
Table 1. Rose materials used in RAPD study.

\begin{tabular}{|c|c|c|c|}
\hline Subgenus & Section $^{2}$ & Rosa species & $\begin{array}{l}\text { Number of } \\
\text { accessions }\end{array}$ \\
\hline \multirow[t]{35}{*}{ Eurosa L. } & \multirow{2}{*}{ Chinenses Sér. } & R. chinensis Jacq. & 8 \\
\hline & & R. ×odorata (Andr.) Sweet. & 1 \\
\hline & \multirow[t]{2}{*}{ Banksianae Lindl } & R. banksiae Ait. & 9 \\
\hline & & $R . \times$ fortuniana Lindl. & 1 \\
\hline & Laevigatae Thory. & R. laevigata Michx. & 3 \\
\hline & \multirow{2}{*}{ Bracteatae Thory. } & R. bracteata Wendl. & 5 \\
\hline & & R. clinophylla Thory & 3 \\
\hline & \multirow[t]{9}{*}{ Synstylae DC } & R. brunonii Lindl. & 5 \\
\hline & & R. filipes Rehd. \& Wils. & 1 \\
\hline & & R. gentiliana Rehd. \& Wils. & 1 \\
\hline & & R. luciae Franch. \& Rochebr. & 2 \\
\hline & & R. moschata Herrm. & 5 \\
\hline & & R. mulliganii Bouleng. & 2 \\
\hline & & R. multiflora Thunb. & 15 \\
\hline & & R. setigera Michx. & 6 \\
\hline & & R. wichuraiana Crép. & 5 \\
\hline & \multirow[t]{5}{*}{ Pimpinellifoliae DC } & R. hugonis Hemsl. \& Wils. & 2 \\
\hline & & R. omeiensis Rolfe & 3 \\
\hline & & R. primula Bouleng & 5 \\
\hline & & R. xanthina Lindl. & 1 \\
\hline & & R. sericea Lindl. & 3 \\
\hline & \multirow{11}{*}{$\begin{array}{r}\text { Cassiorhodon Dumort } \\
\text { (Cinnamomeae DC) }\end{array}$} & & \\
\hline & & R. arkansana Porter. ${ }^{y}$ & 1 \\
\hline & & R. blanda Ait. & 2 \\
\hline & & R. californica Cham. \& Schech & 2 \\
\hline & & R. majalis Herrm. & 2 \\
\hline & & R. ×paulii Rehd. & 1 \\
\hline & & $R$. rugosa Thunb. & 19 \\
\hline & & R. woodsii Lindl. & 4 \\
\hline & & $R$. forrestiana Bouleng. & 1 \\
\hline & & R. davurica Pallas & 1 \\
\hline & & R. macrophylla Lindl. & 1 \\
\hline & \multirow[t]{3}{*}{ Carolinae Crép. ${ }^{y}$} & R. carolina $\mathrm{L}$. & 1 \\
\hline & & R. foliolosa Torr. \& Gray & 4 \\
\hline & & R. nitida Willd. & 1 \\
\hline Platyrhodon Rehd. & & R. roxburghii Tratt. & 9 \\
\hline \multicolumn{4}{|l|}{ Hesperhodos } \\
\hline Cockerell ex Rehder & & R. minutifolia Engelm. & 3 \\
\hline
\end{tabular}

${ }^{2}$ Taxonomic treatment according to Trees and Shrubs Hardy in British Isles (Bean, 1970). The plants used are mainly diploids.

${ }^{\mathrm{y}}$ Tetraploids.

in volumes of $12.5 \mu \mathrm{L}$ containing $10 \mathrm{~mm}$ Tris$\mathrm{HCl}(\mathrm{pH} 8.3$ ) and $50 \mathrm{~mm} \mathrm{KCl}, 3 \mathrm{~mm} \mathrm{MgCl}, 0.1$ mM each of dATP, dCTP, dGTP, and dTTP (Promega), $0.1 \%$ Triton X-100, 0.01\% gelatin, $0.05 \mathrm{ng} \cdot \mu \mathrm{L}^{-1} \mathrm{DNA}, 0.004$ Units AmpliTaq DNA polymerase (Perkin Elmer, Foster City, Calif.), and $1.25 \mathrm{ng} \cdot \mu \mathrm{L}^{-1}(\approx 0.36 \mu \mathrm{M})$ primer. Amplifications were performed in a Thermal Cycler (PTC-100 Programmable Thermal Controller; MJ Research, Watertown, Mass.) programmed for 41 cycles of $1 \mathrm{~min}$. at $92^{\circ} \mathrm{C}$, $1 \mathrm{~min}$. at $35^{\circ} \mathrm{C}, 2 \mathrm{~min}$. at $72^{\circ} \mathrm{C}$. Samples were then stored at $4{ }^{\circ} \mathrm{C}$. Amplification products were subjected to electrophoresis in $2 \%$ agarose gels and visualized by ethidium bromide staining; $1 \mathrm{~kb}$ DNA Ladder (GIBCO BRL, Bethesda, Md.) was used as the size marker. All reactions were repeated at least three times and only reproducible bands were scored.

Data analysis. Each polymorphic band was labeled based upon the primer code and approximate size. For example, F06-0800 represented the 800 bp band amplified by primer F06. Only two character states, present (1) and absent (0), were scored. Ambiguities were scored as missing data. Data were analyzed by the computer program NTSYS-pc (Numerical Taxonomy and Multivariate Analysis System, version 1.80 for PC; Rohlf, 1994) for phenetic analysis using the Dice Coefficient (Clifford and Stephenson, 1975; Nei and Li, 1979; Rohlf, 1994) for calculating the similarity among all 119 taxa with 213 characters. The formula used was:

$$
\text { DICE }=2 a / 2 a+b+c
$$

where ' $a$ ' was the number of bands present in common, and ' $b+c$ ' was the number of bands present in one taxon but absent in the other. The phenogram was constructed with the Unweighted Pair Group Method with Arithmetic Mean (UPGMA) clustering procedure (Rohlf, 1994).

\section{Results and Discussion}

Two hundred thirteen polymorphic markers generated from 10 primers were used to characterize the 119 rose accessions representing a total of 36 rose species. The number of markers detected for each primer varied from 15 (E14) to 30 (H12), with an average of 21.3. The degree of polymorphism with RAPDs detected in this study was greater than in most other plants (Kesseli et al., 1993; Link et al., 1995; Skroch et al., 1993; Tingey et al., 1993).
The rose has a small genome (up to $0.825 \mathrm{pg}$ per haploid genome) (Dickson et al., 1992) and a high level of polymorphism. The high number of bands per primer may also be related to the direct selection of the primers with more polymorphic bands. The size of markers ranged from 260 (E19) to $2300 \mathrm{bp}$ (G11) (Fig. $1)$.

Relationships between the sections and subgenera. The phenogram (Fig. 2) places the roses into two divisions. The second division included only the section Bracteatae. The first division is divided into two groups. Group 1 includes two subgenera, Hesperhodos (group A) and Platyrhodon (group B), as well as two sections of the subgenus Eurosa, Cassiorhodon (group C1 to C4) and Carolinae (group C5 and D). Group 2 includes five sections of the subgenus Eurosa, the sections Banksianae (group E), Synstylae (group F), Chinenses (group G), Pimpinellifoliae (group H), and Laevigatae (group I).

The section Bracteatae (2nd division) is considered to be allied with Banksianae and Laevigatae due to free and caducous stipules (Rehder, 1940), although it is easily distinguished by its deeply incised stipules, large inflorescence bracts, and woolly receptacle (Bean, 1970). Both the isozyme (Kim, 1994) and RAPD analyses indicate that these three sections are distantly related, although the analyses differ from each other in the grouping of these sections with other sections and subgenera. The isozyme data indicated that Bracteatae is allied with the sections Cassiorhodon and Carolinae, and the subgenus Platyrhodon, while the RAPD data clearly separated these species groups. According to Lewis and Basye (1961), the $\mathrm{F}_{1}$ hybrids $R$. bracteata $\times$ rugosa, $R$. bracteata $\times$ foliolosa and $R$. bracteata $\mathrm{x}$ roxburghii are all highly sterile, indicating reproductive barriers between section Bracteatae and sections Cassiorhodon and Carolinae and subgenus Platyrhodon.

In both isozyme (Kim, 1994) and RAPD analyses, Banksianae is allied to the sections Chinenses, Synstylae, and Pimpinellifoliae, whereas Laevigatae is allied with these sections only in the RAPD analyses. The distant relationship among the three sections with free and caducous stipules is further supported by the crossing compatibility studies between Bracteatae and Laevigatae (hybrid seedlings were inviable) and Laevigatae and Banksianae (hybrids were sterile) (Lewis and Basye, 1961)

In the first division, group 1 included the subgenera Hesperhodos and Platyrhodon, and the sections Cassiorhodon and Carolinae. Both subgenera Hesperhodos and Platyrhodon, along with the subgenus Hulthemia, are traditionally classified as being distinct from other roses by their armed fruits (receptacles) (Bean, 1970). Both the isozyme (Kim, 1994) and RAPD analyses grouped the subgenus Platyrhodon with the sections Carolinae and Cassiorhodon.

In contrast with the isozyme data, the RAPD data indicate that the subgenus Platyrhodon is closer to the sections Cassiorhodon and Carolinae than to the section Bracteatae. Rosa 


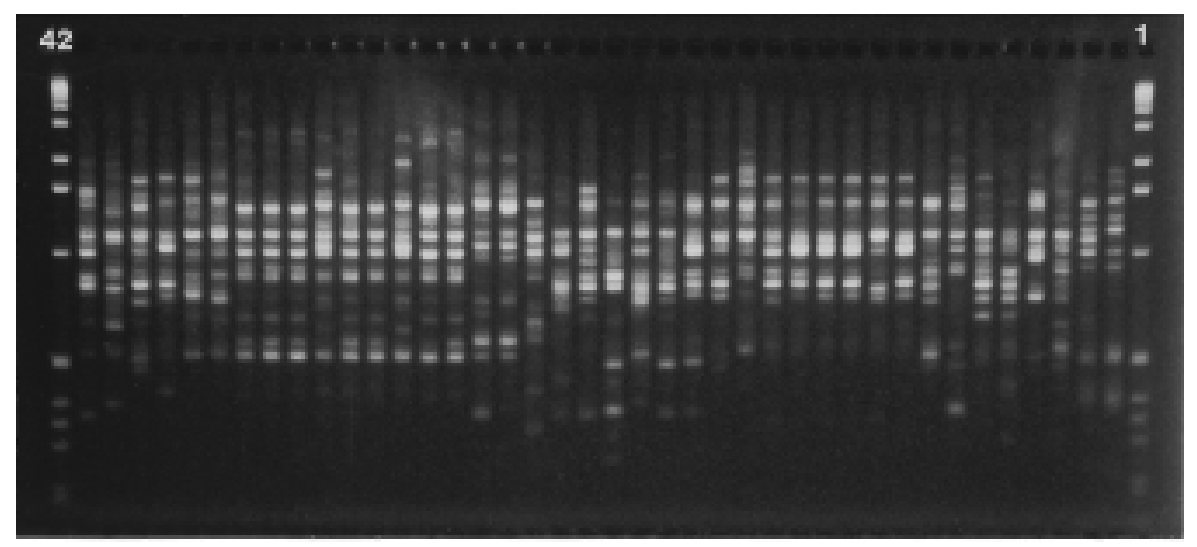

Fig. 1. Gel showing polymorphic banding pattern with G19 primer. Eleven polymorphic bands were scored from this gel. Lane 1 and lane 42 represent $1 \mathrm{~kb}$ DNA ladder (GIBCO BRL). Lanes 2-41 represent the 40 genotypes. Section/subgenus level: Lanes 2-3 = Banksianae; Lanes 4-9 = Synstylae; Lanes 10-18 = Chinenses $;$ Lanes 19-23 = Pimpinellifoliae $;$ Lane 24 = Laevigatae $;$ Lanes 25-26=Bracteatae $;$ Lanes 27-35 = Platyrhodon; and Lanes 36-41 = Cassiorhodon .

roxburghii (subgenus Platyrhodon) is a distinct rose native to China and Japan, which has peeling bark, ovules inserted on a torus at the base of the receptacle (normally inserted at the bottom and on the walls of the receptacle in Eurosa), and a large and spiny fruit with no hint of red in it even when fully ripe (Bean, 1970). Lewis and Basye (1961) reported 60\% successful pollination between $R$. roxburghii and $R$. bracteata, but the resulting $\mathrm{F}_{1}$ hybrids were not fertile ( $99.8 \%$ defective pollen). This further supports the distant relationship between $R$. roxburghii and section Bracteatae (second division of Fig. 2) indicated by the RAPD data.

Rosa roxburghii is currently classified in the monotypic subgenus Platyrhodon because of its unique features, such as peeling bark, ovules inserted on a torus at the base of the receptacle, and large, armed, green receptacles (Bean, 1970; Rehder, 1940). This classification has been questioned because of its crosscompatibility with species in subgenus Eurosa (Lewis and Basye, 1961). In addition, existence of the spontaneous intersectional hybrid, $R$. x micrugosa Henkel ( $R$. roxburghii of the subgenus Platyrhodon with $R$. rugosa of the section Cassiorhodon) that appears to be partially fertile (Bean, 1970), suggests an affinity between these two subgenera (Bean, 1970 Verrier, 1991). The isozyme (Kim, 1994) and RAPD data also show that $R$. roxburghii is linked to the sections Cassiorhodon and Carolinae. Thus, the crossing behavior (Lewis and Basye, 1961), the isozyme data (Kim, 1994), and the RAPD data all support Crépin's (1889) classification system that $R$. roxburghii should be ranked as a section within subgenus Eurosa.

Isozyme and RAPD analyses differ as to the relationship of section Bracteatae with sections Cassiorhodon and Carolinae and subgenus Platyrhodon. Morphological studies (Bean, 1970; Rehder, 1940), the sterility of hybrids with $R$. bracteata and three species: $R$. roxburghii (subgenus Platyrhodon), $R$. rugosa (subgenus Cassiorhodon), and $R$. folialosa (subgenus Carolinae) (Lewis and Basye, 1961) and the RAPD analyses indicate that Bracteatae is distantly related to both sections (Cassiorhodon and Carolinae) and the subgenus Platyrhodon, whereas the isozyme study (Kim, 1994) indicates a closer relationship than traditionally reported (Bean, 1970). Although the preponderance of the evidence supports the traditional viewpoint, further research is needed.

Rosa minutifolia of the subgenus Hesperhodos is a desert species endemic to western Baja California and is distinguished by its five to seven, small, incised leaflets, bractless pedicels, pinnate and erect sepals, narrow stipules with dilated and divergent auricles, tomentose hypanthia with many long prickles, and a few, basally inserted achenes (Lewis, 1965). The species was first classified as the section Minutifoliae by Crépin (1889) and subsequently classified by Parmentier (1898) as a minor branch of section Cinnamomeae (Cassiorhodon), as part of section Spinosissimae Thory (= Pimpinellifoliae) (Baker, 1902,1905), as a separate genus (Hurst, 1928), and, most recently, as a subgenus (Lewis, 1965; Rehder, 1940).

In the RAPD analysis, the three accessions of $R$. minutifolia (subgenus Hesperhodos) have 0.29 similarity level with other roses included in group 1. Section Bracteatae is the most distant group in the analysis, $<0.10$ similarity with all other roses (2nd division). All roses in group 1 have $<0.20$ similarity with those in group 2 (1st division). Within group 2, sections Laevigatae and Banksianae are the most distant (at the 0.20 level). The sections Pimpinellifoliae, Chinenses, and Synstylae follow these. Thus, the RAPD data indicate that Hesperhodos should be ranked as a section within the subgenus Eurosa rather than as a separate subgenus. Since the three other species, (R. mirifica Green, $R$. stellata Wooton, and $R$. vernonii Greene) of the subgenus Hesperhodos were not assayed, further studies are needed to confirm its rank and relationships with other roses.

The sections Cassiorhodon and Carolinae appear closely related to each other (Fig. 2) and are considered within the same section by some authors (Lewis, 1957a). The RAPD data of this study supports combining these two sections. Rehder (1940) classified them together based on the characters of adnate and persistent stipules, styles little or not exserted from receptacles, corymbose inflorescence, usually straight prickles and bristles at base of stems, and entire sepals. Cassiorhodon is the only taxonomic section that is widely represented by species in both the Old and the New Worlds. The close relationship between these two sections is also supported by the high fertility among some $F_{1}$ intersectional hybrids (Lewis and Basye, 1961) and isozyme data (Kim, 1994).

Group 2 includes sections Banksianae, Synstylae, Chinenses, Pimpinellifoliae, and Laevigatae of the subgenus Eurosa. The species are grouped well within each section. Two unidentified accessions that appear to be hybrids with Rosa multiflora clustered with the section Synstylae. Selections from the section Chinenses have contributed more to the formation of modern garden roses than any other section (Bean, 1970) because of their repeat flowering, climbing or trailing habit, and disease resistance (Shepherd, 1954). No systematic study of the crossing behavior between this section and others have been made, but some crosses have been attempted. Rosa calocarpa (André) Willm., a hybrid between $R$. chinensis and $R$. rugosa, is a strong-growing shrub with good fertility (Krüssmann, 1981; Svejda, 1975). Other crosses made between $R$. rugosa and $R$. chinensis to combine the hardiness of $R$. rugosa with the everblooming habit of $R$. chinensis, resulted in $\mathrm{F}_{1}$ hybrids that were mostly sterile (Svejda, 1975, 1978). Another intersectional hybrid, $R$. ×manettii Crivelli, is a hybrid between $R$. chinensis and $R$. moschata (Synstylae), also known as $R$. ×noisettiana Theory (Krüssmann, 1981). Rosa $\times$ manettii is a vigorous plant (Cairns, 1993) and is often used as a budding understock, as it can be propagated easily from cuttings (Krüssmann, 1981). The hybrid between $R$. multiflora $\times R$. chinensis, one of the origins of the polyantha roses, is a low-growing bush with many small flowers (Krüssmann, 1981). Crosses between the species in the sections Synstylae and Chinenses showed $8 \%$ seed setting and $35 \%$ seeds with mature embryos (Ratsek et al., 1940). The isozyme data (Kim, 1994), like the phenogram from the RAPD data, showed that the section Synstylae is allied to Chinenses. Morphologically, the sections Synstylae and Chinenses are related to each other based on adnate and persistent stipules and exserted styles (Rehder, 1940).

Although the genus Rosa is highly variable, the grouping of the species by RAPD data largely agree with the traditional rose taxonomy, cytology, crossing behavior, and isozyme data. Both the subgenera Hesperhodos and Platyrhodon are grouped with the sections Cassiorhodon and Carolinae in the dendrogram of RAPD data. Therefore, sectional ranks are suggested for these two subgenera. The section Carolinae has been classified either as a separate section or as a part of the section Cassiorhodon, based on their morphology and crossing behavior. The isozyme and RAPD 


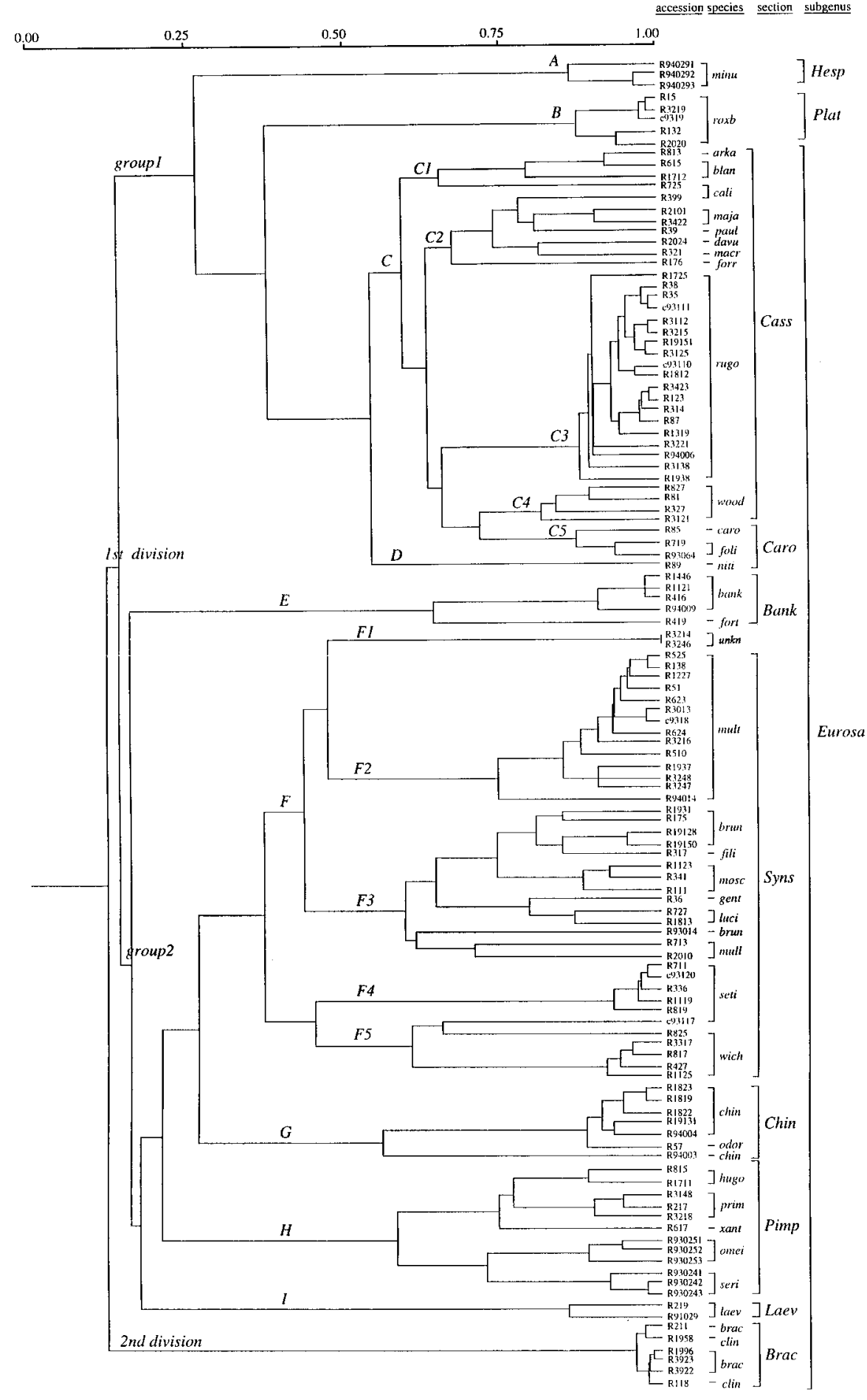

Fig. 2. Phenogram derived from 119 rose accessions and 213 RAPD markers using Dice similarities (also Nei and Li) and UPGMA analysis. Species level: arka $=$ Rosa arkansana; bank $=R$. banksiae; blan $=$ $R$. blanda $;$ brac $=R$. bracteata $;$ brun $=R$. brunonii; cali $=R$. californica $;$ caro $=R$. carolina $;$ chin $=$ $R$. chinensis; clin $=R$. clinophylla; unkn $=$ unknown taxa $(R$. multiflora hybrid $) ;$ davu $=R$. davurica; fili $=R$. filipes; foli $=R$. foliolosa $;$ forr $=R$. forrestiana $;$ fort $=R . \times$ fortuniana $;$ gent $=R$. gentiliana; hugo $=R$. hugonis; laev $=R$. laevigata $;$ luci $=R$. luciae; macr $=R$. macrophylla $;$ maja $=R$. majalis; minu $=$ R. minutifolia $;$ mosc $=R$. moschata $;$ mull $=$ R. mulliganii; mult $=R$. multiflora $;$ niti $=R$. nitida; odor $=R . \times$ odorata $;$ ome $=R$. omeiensis; paul $=R . \times$ paulii; prim $=R$. primula $;$ roxb $=R$. roxburghii; rugo $=R$. rugosa $;$ seri $=R$. sericea $;$ set $=R$. setigera $;$ wich $=R$. wichuraiana $;$ wood $=R$. woodsii $;$ xant $=R$. xanthina. Section level: Bank = Banksianae; Brac = Bracteatae; Caro = Carolinae $;$ Cass $=$ Cassiorhodon $;$ Chin $=$ Chinenses $;$ Laev $=$ Laevigatae $;$ Pimp $=$ Pimpinellifoliae $;$ Syns $=$ Synstylae . Subgenus level: Euro = Eurosa Hesp = Hesperhodos; Plat $=$ Platyrhodon . data support the combination of section Carolinae with section Cassiorhodon. The sections Bracteatae, Banksianae, and Laevigatae are considered closely related to each other based on morphology. However, neither crossing behavior nor isozyme data support a close relationship. The dendrogram (phenetic analysis) of RAPD data in this study indicated that these three sections are distantly and almost equally related to each other. The section Chinenses is grouped with the section Synstylae based on morphology, isozyme, and RAPD data.

\section{Literature Cited}

Allen, E.F. 1973. A simplified rose classification for gardeners. The Rose Annu. 1973:133-139 (The Royal National Rose Society).

Allen, R.C. 1969. Rose classification. Amer. Rose Annu. 54:29-32.

Baker, J.G. 1902. On two new roses from the southwestern United States. J. Royal Hort. Soc. 27:455-457.

Baker, J.G. 1905. A revised classification of roses. J. Linn. Soc. Bot. 37:70-79.

Bean, W.J. 1970. Rosaceae, p. 35-152. In: G. Taylor (ed.). Trees and shrubs hardy in the British Isles. J. Murray, London

Byrne, D.H., W. Black, Y. Ma, and H.B. Pemberton. 1996. The use of amphidiploidy in the development of blackspot resistant rose germplasm. Acta Hort. 424:269-272.

Cairns, T. 1993. Modern roses 10: The comprehensive list of roses of historical and botanical importance. Amer. Rose Soc., Shreveport, La.

Clifford, H.T., and W. Stephenson. 1975. An introduction to numerical classification. Academic Press. New York.

Crepin, F. 1889. Sketch of a new classification of roses. J. Royal Hort. Soc. 11:337-352.

Debener, T., C. Bartels, and L. Mattiesch. 1996. RAPD analysis of genetic variation between a group of rose cultivars and selected wild rose species. Mol. Breeding 2:321-327.

Dickson, E.E., K. Arumuganathan, S. Kresovich, and J.J. Doyle. 1992. Nuclear DNA content variation within the Rosaceae. Amer. J. Bot. 79:1081-1086.

Doyle, J.J., and J.L. Doyle. 1987. A rapid DNA isolation procedure for small quantities of fresh leaf tissue. Phytochem. Bul. 19:11-15.

Erlanson, E.W. 1934. Experimental data for a revision of the North American wild roses. Bot. Gaz. 87:443-506.

Flory, W.S. 1950. Pollen condition in some species and hybrids of Rosa with a consideration of associated phylogenetic factors. Virginia J. Sci. $1: 11-59$.

Gallego, F.J. and I. Martinez. 1996. Molecular typing of rose cultivars using RAPDs. J. Hort. Sci. 71(6):901-908.

He, S., H. Ohm, and S. Mackenzie. 1992. Detection of DNA sequence polymorphisms among wheat varieties. Theor. Appl. Genet. 84:573-578.

Hubbard, M., J. Kelly, S. Rajapakse, A. Abbott, and R. Ballard. 1992. Restriction fragment length polymorphisms in rose and their use for cultivar identification. HortScience 27:172-173.

$\mathrm{Hu}$, J., and C.F. Quiros. 1991. Identification of broccoli and cauliflower cultivars with RAPD markers. Plant Cell Rpt. 10:505-511.

Hurst, C.C. 1928. Differential polyploidy in the genus Rosa L. Zeitschr. Indukt. Abst. Vereb. suppl 2:866-906.

Kesseli, R.V., I. Paran, and R.W. Michelmore. 1993. Efficient mapping of specifically targeted ge- 
nomic regions and the tagging of these regions with reliable PCR-based genetic markers, p. 31-36. In: Application of RAPD technology to plant breeding (Joint Plant Breeding Symposia Series). ASSA/ ASHS/ AGA, Minneapolis, Minn.

Kim, Y. 1994. A study of selected species of Rosa using isozyme polymorphisms. MS Thesis, Texas A\&M Univ., College Station, Texas.

Kim, Y. and D.H. Byrne. 1994. Biosystematical classification of genus Rosa using isozyme polymorphisms (abstract). HortScience 29:483.

Kim, Y. and D.H. Byrne. 1996. Interspecific hybrid verification of Rosa with isozymes. HortScience 31:1207-1209.

Kresovich, S., J.G.K. Williams, J.R. McFerson, E.J. Routman, and B.A. Schaal. 1992. Characterization of genetic identities and relationships of Brassica oleracea L. via random amplified polymorphic DNA assay. Theor. Appl. Genet. 85:190-196.

Krüssmann, G. 1981. The complete book of roses Timber Press, Portland, Ore.

Kuhns, L.J., and T.A. Fretz. 1978a. Distinguishing rose cultivars by polyacrylamide gel electrophoresis. I. Extraction and storage of protein and active enzyme from rose leaves. J. Amer. Soc. Hort. Sci. 103:503-508.

Kuhns, L.J., and T.A. Fretz. 1978b. Distinguishing rose cultivars by polyacrylamide gel electrophoresis. II. Isozyme variation among cultivars. J. Amer. Soc. Hort. Sci. 103:509-516.

Lee, J.S., and Kim, Y.R. 1982. Genetic studies on natural populations of Rosa multiflora Thunb. by isozyme and multivariate analyses (Korean). J. Kor. Soc. Hort. Sci. 23:141-162.

Lewis, W.H. 1957a. An introduction to the genus Rosa with special reference to $R$. acicularis. Virginia J. Sci. 8:197-202.

Lewis, W.H. 1957b. Revision of the genus Rosa in Eastern North America: A review. Amer. Rose Annu. 42:116-126.

Lewis, W.H. 1958. Minor forms of North American species of Rosa. Rhodora 60:237-243.

Lewis, W.H. 1965. Monograph of Rosa in North America. V. Subgenus Hesperhodos. Ann. Missouri Bot. Garden 52:99-113.

Lewis, W.H. 1970. Species roses in the United States and their relation to modern roses. Amer. Rose Annu. 55:78-85.

Lewis, W.H. and R.E. Basye. 1961. Analysis of nine crosses between diploid Rosa species. Proc.
Amer. Soc. Hort. Sci. 78:572-579.

Link, W., C. Dixkens, M. Singh, M. Schwall, and A.E. Melchinger. 1995. Genetic diversity in European and Mediterranean faba bean germplasm revealed by RAPD markers. Theor. Appl. Genet. 90:27-32.

Mikanagi, Y., M. Yokoi, Y. Ueda, and N. Saito. 1993. Flower flavonol and anthocyanin distribution in subg. Rosa. Biochem. Syst. Ecol. 23:183-200.

Mikanagi, Y., M. Yokoi, Y. Ueda, N. Saito, H Hirabayashi, and S. Suzuki. 1994. Flower flavonoid distribution in Rosa rugosa Thunb. ex Murray and interspecific Rosa hybrids (Japanese). J. Jpn. Soc. Hort. Sci. 62:857-866.

Millan, T., F. Osuna, S. Cobos, A.M. Torres, and J.I. Cubero. 1996. Using RAPDs to study phylogenetic relationships in Rosa. Theor. Appl. Genet. 92:273-277.

Nei, M. and W.H. Li. 1979. Mathematical model for studying genetic variation in terms of restriction endonucleases. Proc. Natl. Acad. Sci. USA 76:5269-5273.

Okuda, T., T. Yoshida, T. Hatano, M. Iwasaki, M. Kubo, and T. Orime. 1992. Hydrolysable tannins as chemotaxonomic markers in the Rosaceae. Phytochemistry 31:3091-3096.

Parmentier, P. 1898. Recherches anatomiques et taxonomiques sur les rosiers. Ann. Sci. Nat., ser. 8 , Bot. 6:1-175

Paterson, A.H., C.L. Brubaker, and J.F. Wendel. 1993. A rapid method for extraction of cotton (Gossypium spp.) genomic DNA suitable for RFLP or PCR analysis. Plant Mol. Biol. Rptr. 11:122-127.

Ratsek, J.C., W.S. Flory, and S.H. Yarnell. 1940 Crossing relations of some diploid and polyploid species of roses. Proc. Amer. Soc. Hort. Sci. 38:637-654.

Raymond, O., J.P. Biolley, and M. Jay. 1995. Fingerprinting the selection process of ancient roses by means of floral phenolic metabolism. Biochem. Syst. Ecol. 23:555-565.

Rehder, A. 1940. Manual of cultivated trees and shrubs. Macmillan, N.Y.

Rohlf, F.J. 1994. NTSYS-pc: Numerical taxonomy and multivariate analysis system version 1.80 . Exeter Software, Setauket, N.Y.

Sambrook, J., E.F. Fritsch, and T. Maniatis. 1989. Molecular cloning: A laboratory manual. 2nd edition. Cold Spring Harbor Laboratory Press, Cold Spring Harbor, N.Y.
Shepherd, R.E. 1954. History of the rose. Macmillan, N.Y.

Skroch, P., J. Tivang, and J. Neinhuis. 1993. Analysis of genetic relationships using RAPD marker data, p. 26-29. In: Application of RAPD technology to plant breeding (Joint plant breeding symposia series). ASSA/ASHS/AGA, Minneapolis.

Streeper, R.D. 1990. Where the roses grow. Amer. Rose Annu. 75:23-25.

Svejda, F. 1975. New approaches in rose breeding. HortScience 10:564-567.

Svejda, F. 1978. 'Bonavista', 'Elmira', 'Moncton', and 'Sydney' Rosa rugosa $\mathrm{x}$ chinensis hybrids. HortScience 13:308-309.

Tingey, S.V., J.A. Rafalski, and J.G.K. Williams. 1993. Genetic analysis with RAPD markers, p. 3-8. In: Application of RAPD technology to plant breeding (Joint plant breeding symposia series). ASSA/ASHS/AGA, Minneapolis.

Torres, A.M., T. Millan, and J.I. Cubero. 1993. Identifying rose cultivars using random amplified polymorphic DNA markers. HortScience 28:333-334.

United States International Trade Commission. 1995. Fresh cut roses from Colombia and Ecuador. Investigations No. 713-TA-684 and 685 (Final), Washington, D.C.

Vainstein, A. and H. Ben-Meir. 1994. DNA fingerprint analysis of roses. J. Amer. Soc. Hort. Sci. 119:1099-1103.

Verrier, S. 1991. Rosa rugosa. Capability's Books, Deer Park, Wis.

Walker, C.A. and D.J. Werner. 1997. Isozyme and randomly amplified polymorphic DNA (RAPD) analyses of Cherokee rose and its putative hybrids 'Silver Moon' and 'Anemone'. J. Hort. Soc. Hort. Sci. 122:659-664.

Welsh, J., R.J. Honeycutt, M. McClelland, and B.W.S. Sobral. 1991. Parentage determination in maize hybrids using the arbitrarily primed polymerase chain reaction (AP-PCR). Theor. Appl. Genet. 82:473-476.

Williams, J.G.K., A.R. Kubelik, K.L. Livak, J.A. Rafalski, and S.V. Tingey. 1990. DNA polymorphisms amplified by arbitrary primers are useful as genetic markers. Nucleic Acids Res. 18:6531-6535.

Yoneda, K., T. Iida, H. Asano, and M. Suzuki. 1993. Identification of rose species and hybrids by leaf peroxidase isozyme phenotypes (Japanese). Bul. Coll. Agr. Vet. Med. 50:22-25. 